\title{
Editorial
}

\section{Photovoltaic Materials and Devices 2016}

\author{
Bhushan Sopori, ${ }^{1}$ Prakash Basnyat, ${ }^{1}$ and Vishal Mehta ${ }^{2}$ \\ ${ }^{1}$ National Renewable Energy Laboratory, 1617 Cole Boulevard, Lakewood, CO 80401, USA \\ ${ }^{2}$ Mechanical Engineering Department, Ohio Northern University, 525 S Main St, Ada, OH 45810, USA \\ Correspondence should be addressed to Bhushan Sopori; bhushan.sopori@nrel.gov
}

Received 9 August 2016; Accepted 14 August 2016

Copyright (C) 2016 Bhushan Sopori et al. This is an open access article distributed under the Creative Commons Attribution License, which permits unrestricted use, distribution, and reproduction in any medium, provided the original work is properly cited.

\begin{abstract}
Photovoltaic energy continues to grow with about $59 \mathrm{GW}$ of solar PV installed in 2015. While most of the PV production (about 93\%) was Si wafer based, both CdTe and CI(G)S are growing in their shares. There is also continued progress at the laboratory scale in OPV and dye sensitized solar cells. As the market grows, emphasis on reducing the cost of modules and systems continues to grow. This is the fourth special issue of this journal that is dedicated to gathering selected papers on recent advances in materials, devices, and modules/PV systems. This issue contains sixteen papers on various aspects of photovoltaics. These fall in four broad categories of novel materials, device design and fabrication, modules, and systems. A brief description and salient results of these papers are given below. We hope that readers enjoy this issue.
\end{abstract}

Novel Materials. The paper "Enhanced Light Scattering by Preferred Orientation Control of Ga Doped ZnO Films Prepared through MOCVD" by L. G. Bach et al. explores effective approach by employing low temperature $\mathrm{ZnO}$ buffer layer prior to high temperature GZO film growth that can make pyramidal surface structure of GZO film for effective light trapping. U. Mehmood et al.s paper "New 1,3,4-Oxadiazole Based Photosensitizers for Dye Sensitized Solar Cells (DSSCs)" explores the fabrication and characterization of 1,3,4-oxadiazole photosensitizers for photovoltaic application. The paper by M. Kouhnavard et al. entitled "An Efficient Metal-Free Hydrophilic Carbon as a Counter Electrode for Dye-Sensitized Solar Cells" introduces new method for the production of metal-free and cost-effective counter electrode for dye sensitized solar cell by using doctor blading method. P.-L. Chen et al's paper "Wide-Range Enhancement of Spectral Response by Highly Conductive and Transparent $\mu \mathrm{c}$-SiOx:H Doped Layers in $\mu \mathrm{c}-\mathrm{Si}: \mathrm{H}$ and
a-Si:H/ $\mu$ c-Si:H Thin-Film Solar Cells" explores the increase of light absorption in thin film silicon solar cells by $\mathrm{p}$ - and $\mathrm{n}$-type $\mu \mathrm{c}$-SiOx:H layers by using spectral response method.

Device Design and Fabrication. Research paper "Investigation of Boron Thermal Diffusion from Atmospheric Pressure Chemical Vapor Deposited Boron Silicate Glass for N-Type Solar Cell Process Application" by I. Kurachi and K. Yoshioka reveals the thermal boron diffusion from the BSG film and process stability for device surface properties by using newly developed boron diffusion simulator. The paper by K. Opwis et al. entitled "Preparation of a Textile-Based DyeSensitized Solar Cell" presents textile fabrics based new dye sensitized solar cell and deposition techniques of different layers for large area device to achieve low weight, flexibility, and mechanical strength structure. M. G. Flammini et al.s paper "The Influence of Heating Time and Temperature on the Properties of CIGSSe Solar Cells" explains the effect of heat treatment of CIGSSe modules at different temperature for different time.

Modules and Systems. J. Schnabel and S. Valkealahti's paper entitled "Energy Storage Requirements for PV Power Ramp Rate Control in Northern Europe" illustrates the simulations results that explain the behavior of the PV power fluctuation in northern European climatic conditions and requirements for sizing the energy storage system to compensate for the fluctuations. N. Samano et al.s paper "Characterization of Photovoltaic Panels by means of Thermograph Analysis" explains the thermal behavior, defect monitoring, and process control of multicrystalline module by use of thermograph analysis. The paper by A. Alqahtani et al. entitled "Data-Driven Photovoltaic System Modeling Based on Nonlinear System Identification" deals with the documentation 
of a PV system characteristics with a switch mode power convertor which can contribute to the future design and implementation of nonlinear control strategies. The paper "Improving the Performance of a Semitransparent BIPV by Using High-Reflectivity Heat Insulation Film" by H.M. Liu et al. explains the influence of the different heat insulation solar glass structure on the building integrated photovoltaic systems in Taiwan. J. A. R. Hernanz et al.s paper "Sliding Mode Real Time Control of Photovoltaic Systems Using Neural Estimators" explores the novel control for tracking maximum power point while a Boost DC/DC convertor is used in a photovoltaic module. The paper by $\mathrm{D}$. T. Cotfas et al. entitled "Accelerated Life Test for Photovoltaic Cells Using Concentrated Light" introduces new method for the life testing of photovoltaic cells by using light and temperature from a concentrated light solar simulator. M. Hlaili and H. Mechergui's paper "Comparison of Different MPPT Algorithms with a Proposed One Using a Power Estimator for Grid Connected PV Systems" compares several widely adopted MPPT algorithms and proposes one effective method of injecting the high quality sinusoidal current to the grid. M. Emetere et al's paper "A Simple Technique for Sustaining Solar Energy Production in Active Convective Coastal Regions" studies the issue of solar radiation irregularities due to solar shading in the coastal region and proposes a mathematical model to explain the collective solar radiation over a massive coastal area. The paper by A. Taşçığlu et al. entitled "A Power Case Study for Monocrystalline and Polycrystalline Solar Panels in Bursa City, Turkey" introduces study of time dependent power performance and power values that can be generated from mono- and polycrystalline solar panels at the existing environmental condition of Bursa city in Turkey.

Bhushan Sopori Prakash Basnyat Vishal Mehta 

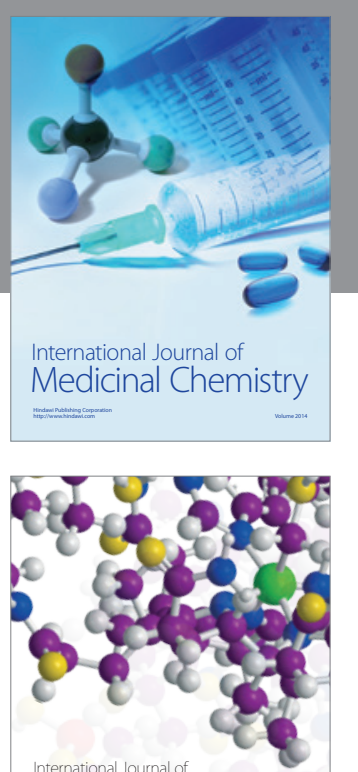

Carbohydrate Chemistry

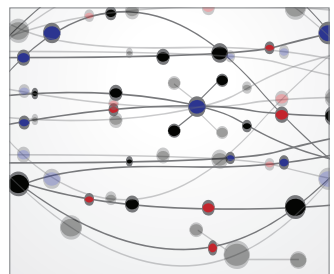

The Scientific World Journal
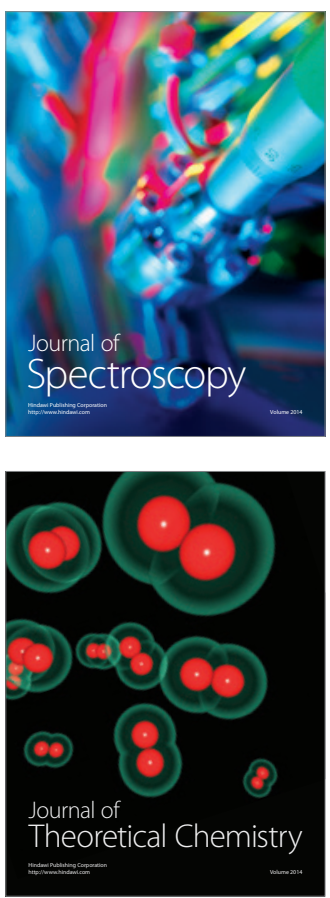
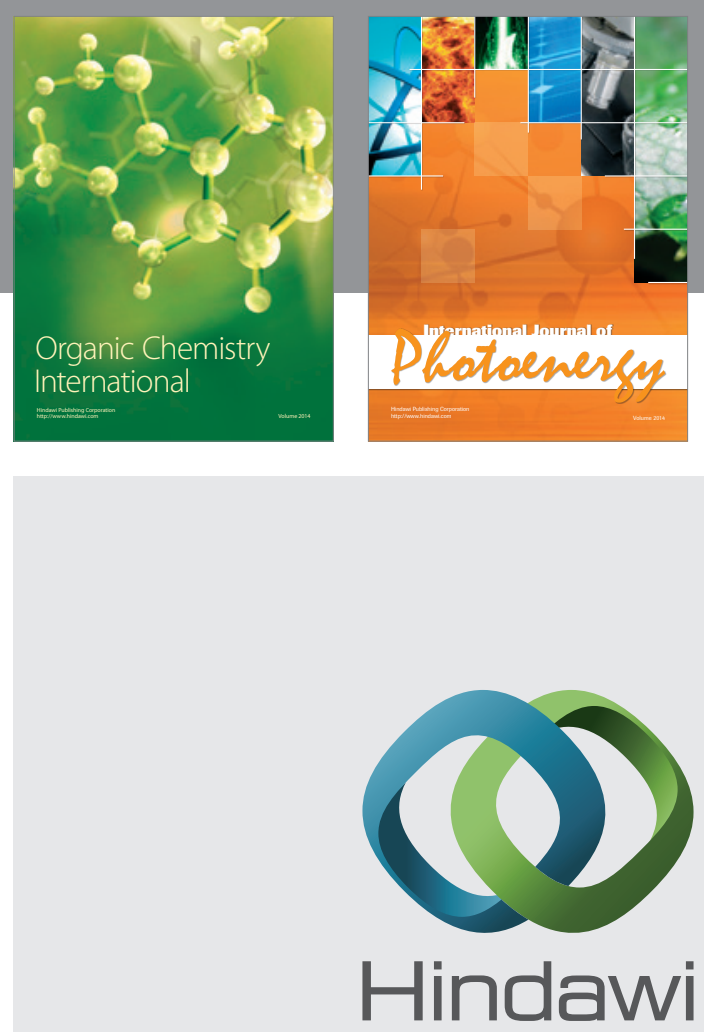

Submit your manuscripts at

http://www.hindawi.com

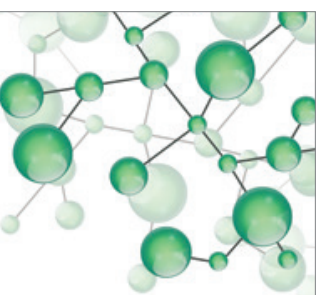

International Journal of

Inorganic Chemistry

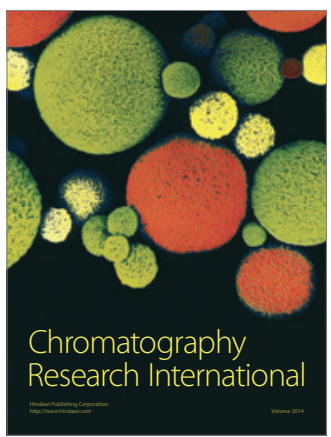

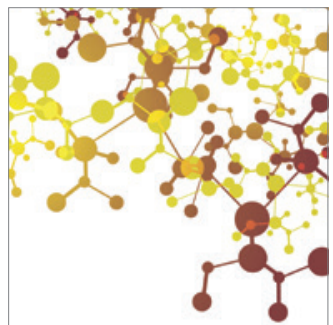

Applied Chemistry
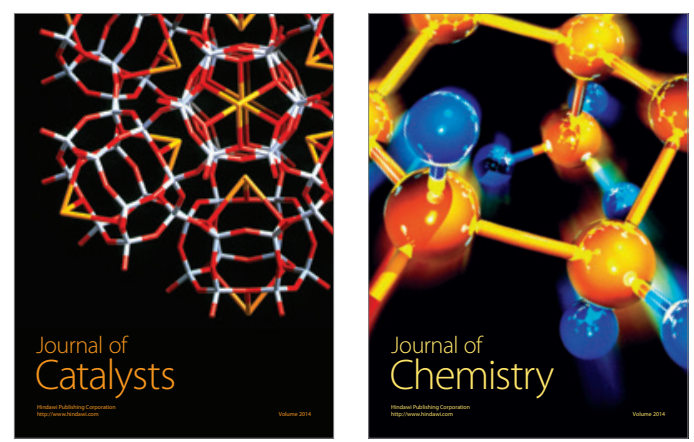
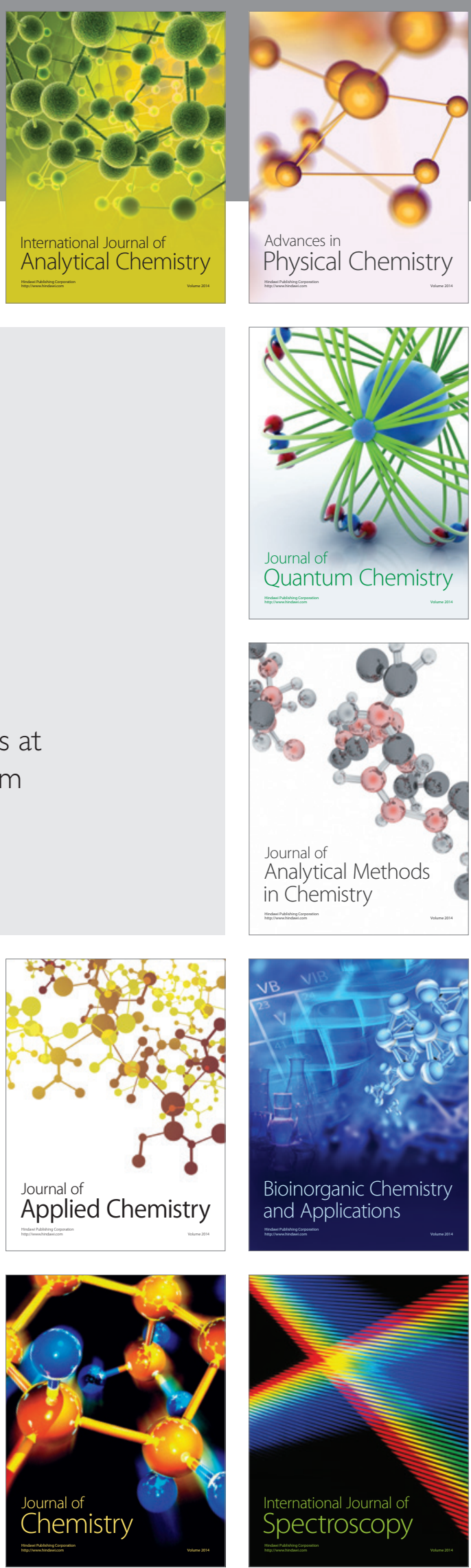